\title{
Antioxidant and Oxidant Status of Medicinal Plant Echium italicum Collected from Different Regions
}

\author{
İmran Uysal ${ }^{1, a, *}$, Falah Saleh Mohammed ${ }^{2, b}$, Ali Erdem Şabik ${ }^{3, c}$, Eylem Kına ${ }^{1, d}$, Mustafa Sevindik ${ }^{4, e}$ \\ ${ }^{I}$ Department of Biology, Faculty of Science and Literature, Gaziantep University, 27410 Gaziantep, Turkey \\ ${ }^{2}$ Department of Biology, Faculty of Science, Zakho University, Zakho, Iraq \\ ${ }^{3}$ Department of Chemistry and Chemical Processing Technologies, Bahçe Vocational School, Osmaniye Korkut Ata University, 80010 \\ Osmaniye, Turkey \\ ${ }^{4}$ Bahçe Vocational High School, Osmaniye Korkut Ata University, 80500 Osmaniye, Turkey \\ ${ }^{*}$ Corresponding author
}

\begin{tabular}{|c|c|}
\hline A R T I C L E I N F O & A B S T R A C T \\
\hline $\begin{array}{l}\text { Received : 19/07/2021 } \\
\text { Accepted : 30/08/2021 }\end{array}$ & $\begin{array}{l}\text { It is known that plants have been used by humans for a very long time in the treatment of diseases. } \\
\text { A wide variety of plant species grown in different regions have been very successful in the treatment } \\
\text { of many diseases. In this study, Echium italicum L. plant collected from different regions was used } \\
\text { as material. The plant was extracted with ethanol in a soxhlet device. Then, antioxidant and oxidant } \\
\text { levels of the plant extract were determined using Rel Assay kits. As a result of the analysis, the TAS } \\
\text { values of the plant were determined } 5.442 \pm 0.240 \text { (Gaziantep), } 4.896 \pm 0.081 \text { (Hakkari) and } \\
6.056 \pm 0.139 \text { (Mersin), TOS values were } 21.372 \pm 0.747 \text { (Gaziantep), } 12.255 \pm 0.341 \text { (Hakkari) and } \\
19.107 \pm 0.438 \text { (Mersin), OSI values were } 0.395 \pm 0.027 \text { (Gaziantep), } 0.250 \pm 0.005 \text { (Hakkari), and } \\
0.316 \pm 0.005 \text { (Mersin). It was observed that antioxidant and oxidant values changed as the regions } \\
\text { where the plant was collected changed. In addition, it was determined that E. italicum could be a } \\
\text { natural antioxidant source. }\end{array}$ \\
\hline
\end{tabular}

Echium italicum

Medicinal plant

Oxidant

Boraginaceae

\section{Introduction}

Since ancient times, people have benefited from plants that they think are medicinal in the treatment of various diseases (Mohammed et al., 2020). It is known that plants that have been used in the treatment of diseases for a very long time have various biological activities ( $\mathrm{Li}$ et al., 2020). These biological activities; such as antimicrobial, antioxidant, analgesic, antiproliferative, anticancer, antiallergic, antihypertensive (Pehlivan et al., 2018; Sevindik, 2018; Fujitaka et al., 2020; Lisa et al., 2020; Maarisit and Lawani, 2020; Ng et al., 2020; Chen et al., 2021). Today, with the use of advanced instrumental methods, it is possible to isolate the components found in plant tissues, even in traces, and to determine their biological activities by making qualitative and quantitative analyzes (Al, 2008). In this context, in this study, total antioxidant, total oxidant and oxidative stress index of $E$. italicum (Boraginaceae) plant were determined. Boraginaceae is a family of plants containing about 100 genera and 2000 species. It is very common in tropical and temperate climates of the world (Özcan, 2008). Echium italicum L. spreads in many regions of Turkey such as calcareous slopes, fallow fields and steppes (Özcan, 2013).

\section{Materials and Methods}

E. italicum specimens were collected from Gaziantep, Hakkari and Mersin provinces of Turkey. Identification of the plant was made using Flora of Turkey volume 6 (Davis, 1978). The aerial parts of the plant samples were dried in a shaded and ventilated environment. The dried samples 
were pulverized. Then, $30 \mathrm{~g}$ of the powder samples were weighed and extracted with $200 \mathrm{~mL} \mathrm{EtOH}$ at $50 \mathrm{OC}$ for approximately 6 hours (Gerhardt EV 14). The solvents of the obtained extracts were removed in the condenser (Heidolph Laborota 4000 Rotary Evaporator).

\section{Total Antioxidant and Oxidant Status}

Total antioxidant (TAS) and oxidant status (TOS) of plant extracts were measured using Rel Assay kits (Erel, 2004; Erel, 2005). Trolox was used as calibrator in TAS tests. Hydrogen peroxide was used as calibrator in TOS tests. OSI (Oxidative stress index) values were determined by proportioning TOS and TAS values (Sevindik, 2019).

\section{Results and Discussion}

\section{Antioxidant and Oxidant Status}

Free radicals are produced by enzymatic or nonenzymatic means in living organisms by environmental effects. The increase in the levels of free radicals causes oxidative stress (Sevindik et al., 2021). Oxidative stress is thought to be effective in the formation of many diseases such as Alzheimer's, Parkinson's, cardiological disorders and cancer in humans (Babaei et al., 2020; Eraslan et al., 2021). Antioxidant defense system functions in reducing the effects of oxidative stress. In cases where the antioxidant defense system is insufficient, the use of supplemental antioxidants is very important (Mushtaq et al., 2020; Khazaei et al., 2021). Plants produce biologically active compounds with many medicinal properties. These plants are preferred in complementary medicine due to their antioxidant properties (Ogbe et al., 2020; Mohammed et al., 2021). In this context, the antioxidant and oxidant potential of E. italicum was determined in order to determine the antioxidant properties of the supplement. The results obtained are shown in Table 1.

There is no data in the literature on TAS, TOS and OSI values of E. italicum. In this context, it was determined for the first time in this study. It has been reported that $E$. italicum has antioxidant activities in previous studies using different methods and solvents (Eruygur et al., 2012; Bošković et al., 2017). In our study, it was determined that E. italicum has significant antioxidant potential. In the samples collected from different regions of the plant, the highest TAS value was measured in the samples collected from Mersin province, and the highest TOS and OSI values were measured in the samples collected from Gaziantep province. According to these results, it was seen that the growing areas of the plant changed the antioxidant and oxidant values.

Table 1. TAS TOS and OSI Values of Echium italicum samples

\begin{tabular}{l|ccc}
\hline \multicolumn{1}{c|}{ Locations } & TAS & TOS & OSI \\
\hline Hakkari & $4.896 \pm 0.081$ & $12.255 \pm 0.341$ & $0.250 \pm 0.005$ \\
Gaziantep & $5.442 \pm 0.240$ & $21.372 \pm 0.747$ & $0.395 \pm 0.027$ \\
Mersin & $6.056 \pm 0.139$ & $19.107 \pm 0.438$ & $0.316 \pm 0.005$ \\
\hline
\end{tabular}

*Values are presented as mean $\pm \mathrm{SD}$.

In addition, in studies on the TAS values of different plant species, the TAS values of Mentha longifolia subsp. longifolia, Allium calocephalum, Salvia absconditiflora, Thymbra spicata, Scorzonera papposa, Adiantum capillusveneris and Marrubium globosum were reported as 3.628, 5.853, 7.350, 8.399, 5.377, 3.086, and 3.086, respectively. TOS values were reported as 4,046, 16,288, 8,501, 6,530, $24,199,21,532$, and 12,387 , respectively. OSI values were reported as $0.112,0.278,0.116,0.078,0.456,0.698$, and 0.162 , respectively (Sevindik et al., 2017; Mohammed et al., 2019a; Mohammed et al., 2019b; Akgül et al., 2020; Mohammed et al. al., 2020a; Mohammed et al., 2020b; Pehlivan et al., 2021). Compared to these studies, the highest TAS value of $E$. italicum was found to be higher than $M$. longifolia subsp. longifolia, A. calocephalum, $S$. papposa and A. capillus-veneris, and lower than $S$. absconditiflora, T. spicata and M. globosum. The TAS value shows all of the antioxidant-effective compounds produced in the plant and functioning in the antioxidant defense system (Mohammed et al., 2018). In our study, it was determined that E. italicum has antioxidant potential and can be used as a natural antioxidant agent in this context. In addition, TOS values show the oxidant compounds produced as a result of environmental effects and metabolic activities within the plant. In addition, OSI values show how much oxidant compounds are suppressed with the help of antioxidant defense system. It is seen that the increase in OSI values makes the antioxidant defense system less effective (Mohammed et al., 2018). In our study, it was observed that TOS values also changed when the localities where the same plant species were collected changed. Compared to these studies, the highest TOS and OSI values of E. italicum were found to be higher than $M$. longifolia subsp. longifolia, A. calocephalum, $S$. absconditiflora, T. spicata and M. globosum, and lower values compared to $S$. papposa and A. capillus-veneris. As a result of the studies, it was concluded that E. italicum can be an important natural antioxidant source.

\section{Conclusion}

In this study, antioxidant and oxidant status of $E$. italicum samples collected from different regions were determined and compared. As a result of the studies, it was observed that the antioxidant and oxidant values of $E$. italicum samples collected from Gaziantep, Hakkari and Mersin provinces changed. In addition, it was determined that E. italicum could be an important natural antioxidant agent.

\section{References}

Akgul H, Korkmaz N, Dayangaç A, Sevindik M. 2020. Antioxidant potential of endemic Salvia absconditiflora. Turkish Journal of Agriculture-Food Science and Technology, 8(10): 2222-2224.

Al H. 2008. Natural products in drug discovery Drug Discov. Today, 13: 894-901.

Babaei F, Moafizad A, Darvishvand Z, Mirzababaei M, Hosseinzadeh H, Nassiri-Asl M. 2020. Review of the effects of vitexin in oxidative stress-related diseases. Food science \& nutrition, 8(6): 2569-2580. 
Bošković ID, Đukić DA, Mašković PZ, Mandić LG. 2017. Phytochemical composition and biological activity of Echium italicum L. plant extracts. Bulgarian Chemical Communications, 49: 836-845.

Chen L, Wang L, Shu G, Li J. 2021. Antihypertensive Potential of Plant Foods: Research Progress and Prospect of PlantDerived Angiotensin-Converting Enzyme Inhibition Compounds. Journal of Agricultural and Food Chemistry, 69(18): 5297-5305.

Davis PH. 1978. Flora of Turkey and the East Aegean Islands. Vol. 6. Edinburgh University Press, Edinburgh, UK

Eraslan EC, Altuntas D, Baba H, Bal C, Akgül H, Akata I, Sevindik M. 2021. Some Biological Activities and Element Contents of Ethanol Extract of Wild Edible Mushroom Morchella esculenta. Sigma: Journal of Engineering \& Natural Sciences/Mühendislik ve Fen Bilimleri Dergisi, 39(1): 24-28.

Erel O. 2004. A novel automated direct measurement method for total antioxidant capacity using a new generation, more stable ABTS radical cation. Clinical biochemistry, 37(4): 277-285.

Erel O. 2005. A new automated colorimetric method for measuring total oxidant status. Clinical biochemistry, 38(12): 1103-1111.

Eruygur N, Yilmaz G, Üstün O. 2012. Analgesic and antioxidant activity of some Echium species wild growing in Turkey. FABAD Journal of Pharmaceutical Sciences, 37(3): 151.

Fujitaka Y, Hamada H, Hamada H, Iwaki T, Shimoda K, Kiriake Y, Saikawa T. 2020. Synthesis of Glycosides of $\alpha$ Tocopherol, Daidzein, Resveratrol, Hesperetin, Naringenin, and Chrysin as Antiallergic Functional Foods and Cosmetics. Natural Product Communications, 15(9): 1934578 X20944666.

Khazaei H, Pesce M, Patruno A, Aneva IY, Farzaei MH. 2021. Medicinal plants for diabetes associated neurodegenerative diseases: A systematic review of preclinical studies. Phytotherapy Research, 35(4): 1697-1718.

Lisa SR, Islam MK, Qais N. 2020. Plants and Plant Constituents with Analgesic and Anti-inflammatory Activities: A Systematic Review. Dhaka University Journal of Pharmaceutical Sciences, 19(2): 207-224.

Maarisit W, Lawani M. 2020. Chemical Investigation and Antimicrobial Activity of Medicinal Plant Toddalia asiatica Lam. Indonesian Journal of Chemistry, 20(5): 1025-1031.

Mohammed FS, Akgul H, Sevindik M, Khaled BMT. (2018). Phenolic content and biological activities of Rhus coriaria var. zebaria. Fresenius Environmental Bulletin, 27(8), 56945702.

Mohammed FS, Günal S, Pehlivan M, Doğan M, Sevindik M, Akgül H. 2020. Phenolic content, antioxidant and antimicrobial potential of endemic Ferulago platycarpa. Gazi University Journal of Science, 33(4): 670-677.

Mohammed FS, Günal S, Şabik AE, Akgül H, Sevindik M. 2020. Antioxidant and Antimicrobial activity of Scorzonera papposa collected from Iraq and Turkey. Kahramanmaraş Sütçü İmam Üniversitesi Tarım ve Doğa Dergisi, 23(5): 1114-1118.
Mohammed FS, Karakaş M, Akgül H, Sevindik M. 2019. Medicinal properties of Allium calocephalum collected from Gara Mountain (Iraq). Fresen Environ Bull, 28(10): 74197426.

Mohammed FS, Kına E, Sevindik M, Dogan M, Pehlivan M. 2021. Datura stramonium (Solanaceae): Antioxidant and Antimicrobial Potentials. Turkish Journal of AgricultureFood Science and Technology, 9(4): 818-821.

Mohammed FS, Sevindik M, Bal C, Akgül H, Selamoglu Z. 2019. Biological Activities of Adiantum capillus-veneris Collected from Duhok Province (Iraq). Communications Faculty of Sciences University of Ankara Series C Biology, 28(2): 128142.

Mohammed FS, Şabik AE, Sevindik E, Pehlivan M, Sevindik M. 2020. Determination of Antioxidant and Oxidant Potentials of Thymbra spicata Collected from Duhok-Iraq. Turkish Journal of Agriculture-Food Science and Technology, 8(5): 1171-1173.

Mushtaq W, Baba H, Akata İ, Sevindik M. 2020. Antioxidant potential and element contents of wild edible mushroom Suillus granulatus. Kahramanmaraş Sütçü İmam Üniversitesi Tarım ve Doğa Dergisi, 23(3): 592-595.

Ng ZX, Yong PH, Lim SY. 2020. Customized drying treatments increased the extraction of phytochemicals and antioxidant activity from economically viable medicinal plants. Industrial Crops and Products, 155: 112815.

Ogbe AA, Finnie JF, Van Staden J. 2020. The role of endophytes in secondary metabolites accumulation in medicinal plants under abiotic stress. South African Journal of Botany, 134: 126-134.

Özcan T. 2008. Analysis of the total oil and fatty acid composition of seeds of some Boraginaceae taxa from Turkey. Plant Systematics and Evolution, 274(3): 143-153.

Özcan T. 2013. Molecular (RAPDs and Fatty acid) and micromorphological variations of Echium italicum L. populations from Turkey. Plant systematics and evolution, 299(3): 631-641.

Pehlivan M, Mohammed FS, Sevindik M, Akgul H. 2018. Antioxidant and oxidant potential of Rosa canina. Eurasian Journal of Forest Science, 6(4): 22-25.

Pehlivan M, Mohammed FS, Şabik AE, Kına E, Dogan M, Yumrutaş Ö, Sevindik M. 2021. Some Biological activities of ethanol extract of Marrubium globosum. Turkish Journal of Agriculture-Food Science and Technology, 9(6): 1129-1132.

Sevindik M. 2018. Pharmacological properties of Mentha species. J Tradit Med Clin Natur, 7(2): 259.

Sevindik M. 2019. Wild edible mushroom Cantharellus cibarius as a natural antioxidant food. Turkish Journal of AgricultureFood Science and Technology, 7(9): 1377-1381.

Sevindik M, Akgul H, Pehlivan M, Selamoglu Z. 2017. Determination of therapeutic potential of Mentha longifolia ssp. longifolia. Fresen Environ Bull, 26(7): 4757-4763.

Sevindik M, Akgul H, Selamoglu Z, Braidy N. 2021. Antioxidant, antimicrobial and neuroprotective effects of Octaviania asterosperma in vitro. Mycology, 12(2): 128-138. 